Original Article (short paper)

\title{
A multidisciplinary weight-loss program: the importance of psychological group therapy
}

\author{
Gustavo Duarte Ferrari \\ Milton Azevedo \\ Leonardo Medeiros \\ Carmem Beatiz Neufeld \\ Rosane Pilot Pena Ribeiro \\ Universidade de São Paulo, Ribeirão Preto, SP, Brasil \\ Bernard Pimentel Rangé \\ Universidade Federal do Rio de Janeiro, Rio de Janeiro, RJ, Brasil \\ Carlos Roberto Bueno Júnior \\ Universidade de São Paulo, Ribeirão Preto, SP, Brasil
}

\begin{abstract}
In addition to dietary factors and sedentary habits, there is a relationship between obesity and psychological variables, even without a clear distinction between cause, effect, and correlation. Despite this relationship, weight-loss programs are limited to a combination of nutrition and physical education, leaving psychological intervention out of the treatment plan. Self-esteem issues, depression, and anxiety are just some of the emotional conditions related to obesity. However, there is no information in the literature about the importance of psychological counseling in a multidisciplinary program for weight-loss in adults. In this context, the main objective of this study was to analyze the effect of cognitive-behavioral therapy in groups (CBTG) combined with nutrition and physical education within a multidisciplinary approach to treat obesity. 46 individuals ( 7 men and 39 women) were divided into two groups: control (GC) and psychology (GP). Baseline and intervention measures were obtained prior to intervention and before the final meeting,including physical capacity tests and the administering the International Physical Activities Questionnaire (IPAQ). Both groups attended weekly lectures given by a nutritionist and two physical education professionals for 12 weeks. In addition, the GP participated in weekly sessions of CBTG for the same period. After the program, there were significant changes in body mass index, waist circumference, body fat percentage, and strength of the lower limbs in both groups. In addition to these changes, the GP also showed improvements in diastolic blood pressure and IPAQ scores, being the only one that increased its time of weekly physical activity. Thus, it was concluded that the psychological treatment might play an important role in a multidisciplinary weight-loss program.
\end{abstract}

Keywords: obesity, exercise, nutrition, cognitive-behavioral group therapy

\section{Introduction}

Obesity and overweight are considered a worldwide health problemof pandemic proportions ${ }^{1}$ that affects approximately $35 \%$ of the world's adult population ${ }^{2}$. It is estimated that at least 2.8 million people die each year from complications of obesity, such as hypertension, hypercholesterolemia, hypertriglyceridemia, and diabetes ${ }^{2}$. Weight gain occurs when energy intake exceeds the daily energy requirements of an individual, resulting in energy storage in the form of adipose tissue. Thus, dietary control associated with physical activity is extremely important for the maintenance of healthy weight and/or weightloss. This importance was observed in studies that performed physical activity interventions with and without concomitant nutritional control ${ }^{3,4}$.

In a peer-reviewed report on weight maintenance,Elfhag Rössner ${ }^{5}$ claimed that most people who lose weight will regain it. Given this, it is possible to estimate that although a beneficial result may occur on an intervention period, everlasting changes in lifestyle are required to actually improve health and reduce life-threatening complications. The authors created a table of the main factors that lead to successful weight-loss, including self-control, autonomy, ability to cope with cravings, better confidence, ability to relate to others, self-efficacy, "healthy narcissism," and stability in life. Such aspects are indeed specific to each person andhighlighting the need for an individualized approach to weight management.

In 2007, Varela et al. ${ }^{6}$ conducted a study to assess whether an intervention with physical activity, nutritional control sessions, and group therapy would be effective to reduce the body mass index (BMI) of overweight women. Their results showed a significant reduction in BMI and body fat percentage of the individuals. However, there was no control group, making it difficult to tell if the psychology sessions were directly related to the observed outcomes.

After a review of the literature regarding individual and grouped treatments, Duchesne, Appolinario, Rangé, Fandiño, Moya, Freitas ${ }^{7}$ stated that the cognitive-behavioral therapy (CBT) 
was shown to be most effective psychological approach in the treatment of binge eating. Despite the lack of weight reduction of the participants, those who underwent the CBT reported a reduction of binge eating symptoms and other associated psychological issues (anxiety and depression). These data are corroborated by Neufeld, Moreira, Xavier ${ }^{8}$ and Meyer ${ }^{9}$.Specifically, the central belief systems of obese individuals maintain inadequate feelings and behaviors triggered by dysfunctional thoughts regarding weight, feeding, and self-appreciation ${ }^{10}$. In this regard, the evaluation and correction of such inadequate thoughts may contribute to the treatment of obesity.

The effectiveness of brief CBT interventions on weight-loss among overweight and obese individuals, and the possibility to insert such treatment on primary healthcare has been documented in the literature ${ }^{11-13}$. Bernardi, Cichelero, Vitolo ${ }^{14}$ also suggested the use of CBT on a multidisciplinary weight-loss program. Cavalcanti. ${ }^{15}$ and Cooper ${ }^{16}$ reported similar data regarding the effectiveness of CBT interventions for the reduction and later maintenance of body weight. Strategies for the elaboration of CBT programs for weight-loss have also been proposed. Duarte and Piccoloto ${ }^{17}$ suggest an intervention based upon a model used as treatment for bulimia. The intervention includes strategies for the control of binge-eating episodes, modification of the eating habits, development of techniques towards physical exercise accession, and gradual weight reduction. Moreover, self-esteem, appearance-related anxiety, and modification of dysfunctional beliefs were addressed.The fact that CBT is a strategy that congregates these characteristics on psychological interventions, along with the presented evidences, indicates that it is an adequate choice for our study.

Although psychotherapy can play an important role in psychological issues identified as eligible factors that influence weight gain, such as anxiety, depression, and binge-eating ${ }^{18}$, we were unable to find any clinical trial that isolatedthe psychology variablewithin a multidisciplinary weight-loss program without the direct application of exercise and dietary control.In this context, the aim of this study was to evaluate the role that sessions of cognitive-behavioral group therapy (CBGT) play in the outcome of an educational multidisciplinary weight-loss program.

\section{Methods}

This study was approved by the Ethics Committee in Research of the Faculty Participants were informed of the procedures of the intervention and signed informed consent was obtained. It was expressed to them that they were free to stop participating in the study at any time without consequence.

\section{Participants}

The program lasted 12 weeks, and started with 75 individuals from the urban area of , invited by folders and email in a public university. Inclusion criteria were BMI $>25.9$ $\mathrm{kg} / \mathrm{m}^{2}$ and age $\geq 18$ years. Individuals with uncomplete primary education were excludedbecause they may not comprehend the questionnaires. In order to complete the intervention, a frequency of $75 \%$ was required. After 12 weeks, 46 individuals ( 7 men and 39 women) completed the program with a baseline and intervention measure.

\section{Intervention}

Participants were divided into two groups, psychology (PG) and control (CG). The psychology group (PG) attended a weekly meeting lasting two and a half hours with three distinct parts. The first hour consisted of a CBGT session held bytwo psychology students. The second part consisted of a one-hour lecture performed by a nutritionist, and in the last $30 \mathrm{~min}$, patients attended to a lecture regarding physical education with two professionals from the field of exercise physiology. The control group (CG) followed the same steps, except for the first onehour session of CBGT.

\section{Psychology}

All meetings were conducted by two psychology undergraduate students, duly trained and supervised weekly. During treatment, patients received interventions on cognitive modeling, automatic thoughts, intermediate beliefs, compensatory strategies, core beliefs, cognitive distortions, social skills, and fallback prevention. For more information about the intervention program in CBGT consult Neufeld, Moreira, Xavier ${ }^{8}$.

At the end of each session, patients were given a task to accomplish on the discussed topic. Before the introduction of a new topic the following week, a discussion concerning the last topic was raised and the given task was discussed to assess the understanding and commitment of the participants. Themes not fully absorbed were revised to ensure understanding and enforcement of the proposed interventions.

\section{Nutrition}

The nutritional sessions were conducted by a certified nutritionistfor aperiod of one-hour. At the beginning of every session, the patients had their waist circumference and weight measured and received guidance on how to improve their eating habits based upon their weekly eating report.

During the sessions, the main topics discussed were food calories, light and diet products, label reading, trans fat, information about and food pyramid assembly, artificial and natural sweeteners, "good" and "bad" fats, protein and carbohydrates, and optimal meal choices.

\section{Physical Education}

All sessions regarding physical activity were held by two physical education professionals and lasted $30 \mathrm{~min}$. At the beginning of 
each session, participants were asked about their weekly exercise routine and how they felt during practice. The maintopics of the sessions were the benefits of exercise, medical exams prior to exercise, basal metabolic rate (BMR), measurement and adjustmentof the intensity of exercise at home training, the importance of attendance, workout volume, myths about exercise, metabolic syndrome, esthetics versus health, and stretching.

Prior to the first and last meeting, participants were administered theInternational Physical Activities Questionnaire (IPAQ) and completed the physical capacity tests listed below.

\section{Data Assessment}

All data were collected at two time points, at the beginning of the study (one week before the first session) and at the twelfth session. Participants who did notmeet the criteria ofa $75 \%$ attendance rate were not included in the analysis.

\section{6-min walk}

Aerobic capacity was assessed by the 6 -min walk test ${ }^{19}$. Patients were instructed to walk in a rectangular path (45.7 meters) as fast as possible without running. They were motivated throughout the test and received warnings about the time at the three, four, and five-minutemark.

\section{IPAQ (short version)}

Physical activity during leisure time and at work were evaluated using the International Physical Activity Questionnaire-short version (IPAQ) held in the form of an interview. This method was chosen based upon the reports ofHallalet al..$^{20}$, who stated that the interview method produced more reliable responses than the self-administered method. The results were used to calculate the weekly amount of physical activity performed by each participant.

\section{BMI, weight, height, and waist circumference}

Body composition data were obtained by a bioelectrical impedance analysis (BF-900 Maltron, Rayleigh, UK). Weight, height, and waist circumference (WC) were evaluated by a nurse with a stadiometer and a digital scale. waist circumference was measured at the narrowest part between the lower rib and the iliac crest, as proposed by Bigaard, Spanggaard, Thomsen, Overvad, Tjønneland ${ }^{21}$.

\section{Flexibility and strength}

Flexibility were evaluated by the test proposed by Wells and Dillon $^{22}$-the patients were instructed to remain barefoot and reach as far as possible on the Wells bench without bending their knees.
A sit-to-stand test was performed to evaluate the strength of lower limbs-patients were instructed to do the maximum repetitions possible in 30 seconds $^{23}$.

The strength of the upper limbs was assessed by handgrip strength with a dynamometer; participants performed three attempts with each hand and the mean of three attempts was used ${ }^{24}$.

\section{Statistical Analysis}

The statistical analysis of the collected data was performed using the GraphPad Prism 5 software (GraphPad Software Inc., San Diego, CA, USA). All data obtained from questionnaires and tests were analyzed with a two-way ANOVA for repeated measures. TheBonferronipost-hoc was applied if necessary. The student t-test for independent samples was used to analyze the age of individuals at baseline. Effect size was calculated using the Cohen's $d$ test using means and stand-deviation within groups. The significance level of 0.05 was adopted.

\section{Results}

At baseline, the groups differed only in blood pressure values, as shown in Table 1, but this difference disappeared after the intervention when PG diastolic blood pressure values were subsequently reduced to levels considered normal ${ }^{25}$. Both groups showed significant changes in BMI, WC, and body fat percentage from pre- to post-intervention. Changes in PG were higher (but not statistically significant) than those observed in the CG.

Table 1: Systolic and diastolic blood pressure (SBP, DPB), body mass index (BMI), wait circumference (WC), body fat percentage (FAT $\%)$, metabolic basal rate (MBR).

\begin{tabular}{|c|c|c|c|c|c|c|}
\hline & \multirow{2}{*}{$\mathbf{n}$} & \multicolumn{2}{|c|}{ Control group } & \multirow{2}{*}{ n } & \multicolumn{2}{|c|}{ Psychology group } \\
\hline & & Pre & Post & & Pre & Post \\
\hline $\begin{array}{l}\text { Age } \\
\text { (years) }\end{array}$ & 19 & $46,7 \pm 14,1$ & - & 27 & $46,2 \pm 11,5$ & - \\
\hline $\begin{array}{l}\text { SPB } \\
(\mathrm{mmHg})\end{array}$ & 18 & $115,6 \pm 13,5$ & $115,6 \pm 12,9$ & 26 & $125,2 \pm 11,2 \dagger$ & $120 \pm 8,9$ \\
\hline $\begin{array}{l}\text { DPB } \\
(\mathrm{mmHg})\end{array}$ & 18 & $78 \pm 8,3$ & $77,8 \pm 7,5$ & 26 & $85,4 \pm 12,3 \dagger$ & $79,8 \pm 7,2^{*}$ \\
\hline $\begin{array}{l}\text { BMI } \\
\left(\mathrm{kg} / \mathrm{m}^{2}\right)\end{array}$ & 19 & $31,2 \pm 4,4$ & $30,3 \pm 4,4^{*}$ & 27 & $31,9 \pm 5,3$ & $30,8 \pm 5,0^{*}$ \\
\hline $\begin{array}{l}\text { WC } \\
(\mathrm{cm})\end{array}$ & 19 & $99,8 \pm 10,8$ & $97,9 \pm 10,3^{*}$ & 27 & $102,5 \pm 10,1$ & $100,3 \pm 10,3^{*}$ \\
\hline FAT $\%$ & 19 & $40,8 \pm 7,3$ & $39,8 \pm 6,1^{*}$ & 26 & $41,5 \pm 6,6$ & $38 \pm 8,8^{*}$ \\
\hline $\begin{array}{l}\text { MBR } \\
\text { (Kcal/ } \\
\text { day) }\end{array}$ & 19 & $1440 \pm 194$ & $1422 \pm 191$ & 26 & $1420 \pm 206$ & $1427 \pm 212$ \\
\hline
\end{tabular}

Data expressed in mean $\pm \mathrm{SD}$; Two-way ANOVA for repeated measures; $\mathrm{n}=$ sample size. $*$ Significant difference within group $(\mathrm{P}<0.05)$. $\dagger$ Significant difference between groups $(\mathrm{P}<0.05)$. 
The results of flexibility, handgrip, sit-to-stand, and 6-min walk tests are shown in Table 2 . The PGperformed slightly better in the 6-min walk test between the two evaluations, while the control group showed a small decrease in meters traveled (not statistically significant). Both groups also significantly improved in the sit-to-stand test, again with a little advantage for the PG $(+4.5$ repetitions; Cohen's $d=1.24)$ compared tothe CG $(+2.5$ repetitions; Cohen's $d=0,83$ ). The $C G$ also showed a statistically significant variation in pre- to post-values in flexibility.

Table 2: Flexibility, right-hand handgrip strength (RHS), left-hand handgrip strength (LHS), sit-to-stand and 6-min walk.

\begin{tabular}{lccccccc}
\hline & & \multicolumn{2}{c}{ Control group } & & \multicolumn{2}{c}{ Psychology group } \\
& & Pre & Post & & Pre & Post \\
\hline $\begin{array}{l}\text { Flexibility } \\
\text { (cm) }\end{array}$ & 17 & $24,4 \pm 7,9$ & $27 \pm 7,2^{*}$ & 26 & $22,4 \pm 8,2$ & $23,6 \pm 7,8$ \\
RHS (Kgf) & 17 & $28,8 \pm 5,9$ & $30,1 \pm 8,5$ & 27 & $30,3 \pm 11,6$ & $31,7 \pm 12,0$ \\
LHS (Kgf) & 17 & $25,7 \pm 7,4$ & $28,1 \pm 8,3$ & 27 & $29,3 \pm 10,5$ & $30,5 \pm 11,0$ \\
$\begin{array}{l}\text { Sit-to-stand } \\
\text { (reps) }\end{array}$ & 17 & $14,9 \pm 3,6$ & $17,4 \pm 4,1^{*}$ & 26 & $15,5 \pm 3,9$ & $20,0 \pm 5,5^{*}$ \\
$\begin{array}{l}\text { 6-min walk } \\
\text { (m) }\end{array}$ & 13 & $534 \pm 32$ & $520 \pm 52$ & 26 & $570 \pm 84$ & $583 \pm 63 \dagger$ \\
\hline
\end{tabular}

Data expressed in mean $\pm \mathrm{SD}$; Two-way ANOVA for repeated measures; $\mathrm{n}=$ sample size. *Significant difference within group $(\mathrm{P}<0.05)$. $\dagger$ Significant difference between groups $(\mathrm{P}<0.05)$.

According to IPAQ values, a significant difference in walking time and time of moderate activity on weekdayswas noted only in the PG. No difference was found in the control group for any of the variables evaluated by the questionnaire (Table 3 ).

Table 3: Walking time (T.Walk), moderate physical activity time (T.Mod), vigorous physical activity time (T.Vig), Weekend sitting time (T.Seat).

\begin{tabular}{lccccccc}
\hline & & \multicolumn{2}{c}{ Control group } & & \multicolumn{2}{c}{ Psychology group } \\
\cline { 5 - 6 } & & Pre & Post & & Pre & Post \\
\hline $\begin{array}{l}\text { T.Walk } \\
\text { (min/week) }\end{array}$ & 19 & $110 \pm 165$ & $140 \pm 129$ & 27 & $119,8 \pm 118$ & $220,6 \pm 164^{*}$ \\
$\begin{array}{l}\text { T.Mod } \\
\text { (min/week) }\end{array}$ & 19 & $173 \pm 126$ & $173 \pm 140$ & 27 & $147 \pm 331$ & $303 \pm 340^{*}$ \\
$\begin{array}{l}\text { T.Vig } \\
\text { (min/week) }\end{array}$ & 19 & $67 \pm 130$ & $48 \pm 68$ & 27 & $34 \pm 66$ & $101 \pm 193$ \\
$\begin{array}{l}\text { T.Seat } \\
\text { (min/week) }\end{array}$ & 19 & $268 \pm 143$ & $314 \pm 151$ & 27 & $340 \pm 200$ & $307 \pm 162$ \\
\hline
\end{tabular}

Data expressed in mean $\pm \mathrm{SD}$; Two-way ANOVA for repeated measures; $\mathrm{n}=$ sample size. *Significant difference within group $(\mathrm{P}<0.05)$.

Some individuals developed orthopedic and health problems throughout the intervention (not intervention related), and this resulted in the variability of the sample size in physical capacity tests.

\section{Discussion}

The aim of our study was to evaluate the importance of psychological counseling within a multidisciplinary approach to weight reduction in obese adults without the direct application of exercise sessions and dietary control. A number of studies have tested the importance of nutritional counseling along with exercise routines for weight loss purposes ${ }^{4,26-28}$, but none have tested a psychological intervention as part of the program. This seems to be an important gap in the literature as it has been shown that there are many psychological issues surrounding weight gain and obesity ${ }^{5,18}$.

In particular, Perez and Roman ${ }^{28}$ argue that the psychological issues involved in depression and compulsive eating can be limiting factors in the treatment of metabolic syndrome andstate that a multipronged approach is required during development of a weight loss program. In addition, there are many advertising stimuli related to food and diets, which may affect the individual from an early age and can play an important role in the formation of individual preferences and eating habits ${ }^{29}$. Such stimulation can translate into unhealthy and hypercaloric food choices,making it more difficult for individuals to make healthy choices throughout their life. This makes a psychological intervention critical to provide changesin the lifestyle of individuals and the way they think and interact with food.

However, Caetano, Carvalho, Galindo ${ }^{18}$ found no significant differences in the psychological profile of obese and non-obese individuals. The authors argue that the causes of obesity cannot be generalized and that not every obese person has psychological problems or personality traits related to their weight gain or difficulty with weight-loss. The relationship between obesity and psychological factors seem to be referenced in the literature ${ }^{30}$, but the direction and the type of relationship remains a point under study.

Further, Freitas, Santiago, Viana, Leão, Freyre ${ }^{31}$ asked a group of 120 adults to describe their main reasons for maintaining a regular exercise routine. In order to be as accurate as possible, they split the options into seven main categories: exercise; health; welfare; environment; psychosocial; gym staff; and esthetic reasons. The reasons considered the most important in each group were "feeling good," "to maintain health," "to increase the ability of the body," "I feel fulfilled," "to receive team motivation," and "keep fit."When looking at the answers, especially"feel fulfilled" and "to receive team motivation," we can see that there is an important psychosocial factor around physical activity. When asked about the main reason to start an exercise program, $61.4 \%$ of women selected "improve selfimage" as the main factor, while $45.9 \%$ of men indicated that "peer pressure

wasan important factor. Note that such both factors are also closely linked to psychosocial reasons. Indeed, an active lifestyle is an important factor in weight-loss and there are psychological 
and social aspects surrounding the choice to be active. Therefore, in order to fight the epidemic of obesity, psychological counseling should be of utmost importance in an individual treatment plan.

Our working hypothesis is that the collaborative work between the physical education professional, nutritionist, and psychologist encompass greater health benefits when compared to an intervention without psychological intervention. Such a collaboration creates a more efficient weight-loss program by addressing the psychological factors that influence obesity and weight-loss. Curiously, it seems to be a pattern in the literature that female individuals tend to participate more than males in health and weight-loss interventions $\mathrm{s}^{32-34}$.

Both PG and CG showed significant improvements in BMI, $\mathrm{WC}$, and fat percentage, but changes in the GP group were higher across all variables, especially in body fat percentage $(\Delta=-1 \%$; Cohen's $d=0.40$ in CG and $\Delta=-3.5 \%$; Cohen's $d=1.07$ inPG).

Currently, the WC is considered a risk factor for cardiovascular diseases CVD, and an essential factor for the characterization of metabolic syndrome according to the International Diabetes Federation (IDF) criteria.Therefore, the reduction of this measure is important in a weight-loss and health program ${ }^{35}$. The multidisciplinary approach without exercise application has already been identified as capable of promoting weight-loss and reduction of $\mathrm{CVD}^{36}$, but the greatest benefit of weight-loss is obtained when there is only a reduction of body fat without losing muscle mass. In this context, a reduction of BMI and WC without concomitant reduction in basal metabolic rate (BMR) is indicative of weightlost without loss of muscle mass, since the latter is the main influencer of MBR levels ${ }^{37}$.

In addition to the anthropometric variables, the PG also showed an improvement in diastolic blood pressure levels. It is currently recommended that the diastolic blood pressure (DBP) levels are less than $90 \mathrm{mmHg}$. Despite initial levels of DBP in both groups below this threshold, the $\mathrm{PG}$ values were higherthan the GC levels. After the intervention, the GP showed a reduction in DBP to lower than $80 \mathrm{mmHg}$, on average. Currently the recommended values of DBP are between $70-89 \mathrm{mmHg}$ for protection against $\mathrm{CVD}^{25}$. The systolic blood pressure (SBP) levels also showed a decrease of $5 \mathrm{mmHg}$ on average, without reaching the level of statistical significance. Improvement in lower limb strength was observed for both groups. This shows that an intervention without the application of direct physical activity can increase the fitness of individuals. This phenomenon may be due to enhanced motivation to practice that was generated by the encounters. When correlating these findings with walking time and moderate activity time measured by the IPAQ, it is clear that even without an increase in exercise time, there was an improvement in strength. One possible response to this phenomenon can be an improvement in exercise intensity rather than volume. It is possible that the information passed on to participants concerning correct exercise practice enabled them to perform more efficiently without necessarily increasing practice time.

Although several studies have observed the influence of exercise on WC, BP, and lower limb strength ${ }^{36,38,39}$, we were unable to find any that included a multidisciplinary program without the direct application of exercise, diet, or drug treatment.
Thus, this work seems to be the first to demonstrate that aninformativeprogram is able to generate changes in the lifestyle of individuals,providing them with the tools needed to apply the interventionon their own.

More studies are necessary to establish the importance of psychological intervention within a multidisciplinary program for weight-loss. The literature is sparse in this area. Psychological studies related to obesity are plentiful, but the collaborative work in the areas of physical education, nutrition, and psychology is not being adequately addressed. In conclusion, results indicate that psychological counselingmight play an important role in a multidisciplinary weight-loss program without the direct application of exercise sessions and dietary control.

\section{References}

1. Quinn A, Doody C, O\&apos; Shea D. The effect of a physical activity education programme on physical activity, fitness, quality of life and attitudes to exercise in obese females. J Sci Med Sport. 2008;11(5):469-72.

2. World Health Organization. Obesity and overweight. Fact sheet No311. 2015. Available from:http://www.who.int/mediacentre/ factsheets/fs311/en/

3. Ghroubi S, Elleuch H, Chikh T, Kaffel N, Abid M, Elleuch MH. Physical training combined with dietary measures in the treatment of adult obesity. A comparison of two protocols. Ann Phys Rehabil Med. 2009;52(5):394-413.

4. Monteiro R de C de A, Riether PTA, Burini RC. Efeito de um programa misto de intervenção nutricional e exercício físico sobre a composição corporal e os hábitos alimentares de mulheres obesas em climatério The effects of a mixed program of nutritional. Rev Nutr. 2004;17(4):479-89.

5. Elfhag K, Rössner S. Who succeeds in maintaining weight loss? A conceptual review of factors associated with weight loss maintenance and weight regain. Obes Rev. 2005;6(1):67-85.

6. Varela AL, Quintans CC, Tranqueira APM, Gasparotto R, Isaac IA da S, Estrela RAM, et al. Revista Brasileira de Obesidade, Nutrição e Emagrecimento. Rev Bras Obesidade, Nutr e Emagrecimento. 2007;1(6):12-27.

7. Duchesne M, Appolinario JC, Rangé BP, Fandiño J, Moya T, Freitas SR. The use of a manual-driven group cognitive behavior therapy in a Brazilian sample of obese individuals with bingeeating disorder . Rev. Bras. Psiquiatr. 2007; 23-5.

8. Neufeld CB, Moreira CAM, Xavier GS. Terapia CognitivoComportamental em Grupos de Emagrecimento: O Relato de Uma Experiência. Psico. 2012;43(1):93-100.

9. Meyer E. Terapia Cognitivo-Comportamental na prática psiquiátrica. Porto Alegre: Artmed; 2004. 430-438 p.

10. Abreu CN, Roso M. Psicoterapias cognitiva e construtivista: novas fronteiras da prática clínica. Porto Alegre: Artmed; 2003.

11. Leal I, Branco J, Pimenta F, Maroco J. O peso da mente - Uma revisão de literatura sobre factores associados ao excesso de peso e obesidade e intervenção cognitivo-comportamental. Análise Psicológica. 2009;2:175-87. 
12. Palavras MA, Kaio GH, de Jesus Mari J, Claudino AM. Uma revisão dos estudos latino-americanos sobre o transtorno da compulsão alimentar periódica. Rev Bras Psiquiatr. 2011;33(1):81-94.

13. Tavares Filho TE, Magalhães PMDS, Tavares BM. Terapia cognitivo-comportamental e seus efeitos no tratamento dos transtornos do comportamento alimentar. Rev Psicol da. 2009;1(2):160-8.

14. Bernardi F, Cichelero C, Vitolo MR. Comportamento de restrição alimentar e obesidade. Rev Nutr. 2005;18(1):85-93.

15. Cavalcanti AP. Crenças e influências sobre dietas de emagrecimento entre obesos de baixa renda Beliefs and influences on weight loss diets among low-income obese individuals. Soc Psychol (Gott). 2005;1567-74.

16. Cooper Z, Doll HA, Hawker DM, Byrne S, Bonner G, Eeley E, et al. Testing a new cognitive behavioural treatment for obesity: A randomized controlled trial with three-year follow-up. Behav Res Ther. 2010;48(8):706-13.

17. Duarte ALC, Piccoloto LB. A Terapia CognitivoComportamental no Transtorno de Compulsão Alimentar Periódica (TCP). Tópicos especiais em terapia cognitiva. São Paulo: Casa do Psicólogo; p. $161-80$.

18. Caetano C, Carvalho AMP, Galindo EMC. Obesidade e Aspectos Psicológicos : Maturidade Emocional, Auto-conceito , Locus de Controle e Ansiedade. Psicol Reflexão e Crítica. 2005;18(1):39-46.

19. Guyatt GH, Sullivan MJ, Thompson PJ, Fallen EL, Pugsley SO, Taylor DW, et al. The 6-minute walk: A new measure of exercise capacity in patients with chronic heart failure. Can Med Assoc J. 1985;132(8):919-21.

20. Hallal PC, Gomez LF, Parra DC, Lobelo F, Mosquera J, Florindo AA, et al. Lições Aprendidas Depois de 10 Anos de Uso do IPAQ no Brasil e Colômbia. J Phys Act Health. 2010;7(2):259-64.

21. Bigaard J, Spanggaard I, Thomsen BL, Overvad K, Tjønneland A. Self-reported and technician-measured waist circumferences differ in middle-aged men and women. J Nutr. 2005;135(9):2263-70.

22. Wells KF, Dillon EK. The sit and reach: A test of back and leg flexibility. Am Assoc Heal Phys Educ Recreat. 1952;23(1):115-8.

23. Bohannon RW. Sit-to-stand test for measuring performance of lower extremity muscles. Percept Mot Skills. 1995;80:163-6.

24. Geraldes AAR, Oliveira, Angysnoelia R M O Albuquerque RB, Carvalho JM. A Força de Preensão Manual é Boa Preditora do Desempenho Funcional de Idosos Frágeis : um Estudo Correlacional Múltiplo. Rev Bras Med do Esporte. 2008;14(2):12-6.

25. Franklin SS, Gokhale SS, Chow VH, Larson MG, Levy D, Vasan $\mathrm{RS}$, et al. Does low diastolic blood pressure contribute to the risk of recurrent hypertensive cardiovascular disease events?: The framingham heart study. Hypertension. 2015;65(2):299-305.

26. Bertz F, Brekke HK, Ellegard L, Rasmussen KM, Wennergren M, Winkvist A. Diet and exercise weight-loss trial in lactating overweight and obese women 1 -3. Am J Clin Nutr. 2012;96:698-705.

27. Somerset SM, Markwell K, Al-Foraih M. A systematic review of baseline psychosocial characterisation in dietary randomised controlled trials for weight loss. Eur J Clin Nutr. 2013;67(7):697-702.

28. Perez GH, Romano BW. Comportamento alimentar e síndrome metabólica: aspectos psicológicos. Rev da Soc Cardiol do Estado São Paulo. 2004;14(4):544-50.
29. Quaioti TCB, Almeida S de SA. Determinantes psicológicos do comportamento alimentar: uma ênfase em fatores ambientais que contribuem para a obesidade. Psicol USP. 2006;17(4):193-211.

30. Vasques F, Martins FC, De Azevedo AP. Aspectos psiquiátricos do tratamento da obesidade. Rev Psiquiatr Clin. 2004;31(4):195-8.

31. Freitas CMM, Santiago M de S, Viana A, Leão AC, Freyre C. Motivational aspects that influence the elderly to enroll on and continue participanting in physical exercise programs. Rev Bras Cineantropo Desemp Hum. 2007;9(1):92-100.

32. Coelho-Ravagnani CDF, Pereira AF, Ravagnani FCDP, Michelin E, Corrente JE, Burini RC. Impacto de um programa de intervenção para mudança do estilo de vida sobre indicadores de aptidão física, obesidade e ingestão alimentar de indivíduos adultos. Rev Bras Atividade Física e Saúde. 2010;15(1):21-7.

33. Viana LV, Paula TP de, Leitão CB, Azevedo MJ. Fatores determinantes de perda de peso em adultos submetidos a intervenções dietoterápicas. Arq Bras Endocrinol Metabol. 2013;57(9):717-21.

34. Colombo CM, Macedo RM De, Fernandes-silva MM, Caporal AM, Stinghen AE, Costantini CR, et al. Efeitos de curto prazo de um programa de atividade física moderada em pacientes com síndrome metabólica. Rev Einstein. 2013;11(3):324-30.

35. International Diabetes Federation. The IDF consensus worldwide definition of the metabolic syndrome. IDF Consens Worldw Defin Metab Syndr. 2006;28:1-7.

36. Ferreira FB, Fraga JC da S, Nunes JP, Liberali R, Navarro F. Alterações antropométricas de pacientes obesos submetidos a um tratamento multidisciplinar da obesidade em Porto Alegre. Rev Bras Obesidade, Nutr e Emagrecimento. 2009;3(16):290-7.

37. Cunningham JJ. A reanalysis of the factors influencing basal metabolic rate in normal adults. Am J Clin Nutr. 1980;33(11):2372-4.

38. Medina FL, Lobo FDS, Souza DR De, Kanegusuku H, Forjaz CLDM. Atividade física : impacto sobre a pressão arterial. Rev Bras Hipertens. 2010;17(2):103-6.

39. Silva TO, Glisoi SF das N, Ansai JH, Izzo H. Grupo de assistência multidisciplinar ao idoso ambulatorial : efeitos da abordagem fisioterapêutica. Rev da Soc Bras Clínica Médica. 2014;12(1):2-7.

\section{Acknowledgments}

We thank the National Council for Scientific and Technological Development $(\mathrm{CNPq})$ for the financial support for this research.

\section{Corresponding author}

Gustavo Duarte Ferrari

Escola de Educação Física e Esporte de Ribeirão Preto. Av. Bandeirantes, 3900 Monte Alegre, Ribeirão Preto - SP.

Email: gustavod.ferrari@gmail.com

Manuscript received on June 04, 2016

Manuscript accepted on August 29, 2016

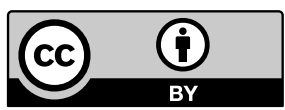

Motriz. The Journal of Physical Education. UNESP. Rio Claro, SP, Brazil - eISSN: 1980-6574 - under a license Creative Commons - Version 3.0 